\title{
The new professionalism and the shift to team teaching
}

\author{
Cecilia Borges, Maurice Tardif \\ Faculty of Education Sciences, Université de Montréal, Montréal, Canada
}

Email address:

cecilia.borges@umontreal.ca (C. Borges), maurice.tardif@umontreal.ca (M. Tardif)

\section{To cite this article:}

Cecilia Borges, Maurice Tardif. The New Professionalism and the Shift to Team Teaching. International Journal of Secondary Education. Vol. 2, No. 2, 2014, pp. 27-33. doi: 10.11648/j.ijsedu.20140202.11

\begin{abstract}
The objective of this paper is to propose a number of new directions for analysis and reflection in the emerging research field of collective teacher work. This paper is organized in two parts: the first situates the issue of collaborative work as part of the reforms and changes that have taken place in the teaching profession since the 1980s; the second relates this issue to the many ways of dividing up teaching work. This paper aims to lay the conceptual groundwork for a field that has been largely unexplored. This work is based on the studies of Professor Tardif's research team on changes in the teaching profession and team teaching systems, and on recent research by Professor Borges on team teaching under secondary school reform programs.
\end{abstract}

Keywords: Teaching Work, Changes in the Teaching Profession, New Professionalism, Division of Labor, Teacher Networks, Collaborative and Collective Work

\section{An Overview of Recent Changes in the Teaching Profession and the Role of Team Teaching}

Most European and North American schools are institutionalizing new forms and practices of collaborative work among teachers and between teachers and non-teaching staff. To better understand the issues involved in this institutionalization and the resistance it provokes, we must first situate it against traditional organizations of teaching work.

Historically, in the 20th century, educational institutions were designed to accommodate the organization teaching work, planned around discrete classroom units under a model known as the "egg-carton" organization, initially described by Lortie, 1975 (See Tardif \& Lessard, 1999 for a review of works on this approach).

Normally, schools are cut off from the surrounding environment. For instance, people cannot just walk in, students are screened before admission, only qualified staff work in them, and internal operations are governed by specific rules. Within the establishment are closed classrooms that are completely separated from one another. As a general rule, each classroom is under the control of a single teacher who works with a particular group of students. Thus, as teachers perform their day-to-day work, the ties between them grow very weak, because teachers usually assume sole responsibility for their main tasks. Thus, the teacher is a worker who is expected to possess all the authority and professional know-how required to perform the job properly and in isolation, namely to teach a given subject to a given group of students in a given classroom.

We note in passing that this type of organization of teaching work looks very much like the organization of school knowledge, i.e., curriculum-based knowledge divided into discrete blocks or units, subjects, disciplines, lessons, pre-determined content, objectives and subobjectives, incorporating pacing and clearly defined steps. Each teacher must "master" not only the class, but also the assigned curriculum and activity areas. This vision of school knowledge is epistemologically analogous to the "egg-carton" organization of the curriculum: each school subject is confined within a well defined cell, with little sharing between subjects, and with no one person having overall responsibility.

Of course, this type of work and knowledge organization does not preclude collaboration (professional and individual, formal and informal) among teachers and between teachers and other school staff, including the administration. Nor does it prevent team teaching or teacher collaboration, or various forms of sharing, for instance sharing teaching materials, tips, ideas, routines and teaching practices. However, these relations and exchanges with other school staff, including fellow teachers, are 
typically side-lines to the central classroom work, which teachers tend to consider inviolable territory. In fact, very few teachers are willing to share their classes with colleagues. In this sense, team teaching certainly takes place, but only at the margins, in the tiny spaces left between the cells of the "egg-carton" organization.

Based on previous findings, one of the questions that guide our research is whether the changes made to the teaching profession since the 1980s have really impacted this organization of teaching work. We are reminded that the 1980s were a pivotal time for the teaching profession internationally, marking the beginning of the movement to professionalize teachers, and on a broader scale, the spread to the education sector of post-Fordist management models (e.g., competition, decentralization, accountability, free market, privatization and privatization) (Maroy, 2006; Lessard, 2000; Tardif \& Lessard, 2004), not to mention the development of ICT in education in the late 1980s. Furthermore, most of the teacher training reforms were initiated in the 1980s and implemented in the 1990s (e.g., the IUFM in France, the HEP in Switzerland, the four-year bachelor's program in Quebec and the professional development school in the United States and Great Britain).

In short, since the 1980s, has the cellular classroom been opened up and the "egg-carton" organization taken apart? In other words, are we in the process, slowly but surely, of moving away from the traditional organization of the profession and toward a reorganization that places high value and emphasis on team teaching, and more broadly, educational work, in other words, the work accomplished by all the school staff?

There are no easy answers to these questions, particularly because we must distinguish between the changes required under the reforms, changes operating at the school and organizational levels, and teaching practices themselves, which vary greatly in this field, as shown in many education studies. Generally speaking, it must be said that recent changes in the teaching profession have been slower than what the reforms envisaged. Moreover, these changes vary wildly across countries and regions, mainly due to factors such as urban area size, local population heterogeneity and professional traditions. Finally, we must note that the reforms have divergent requirements: some promote the development of a collective teaching professionalism; others require teachers to refocus on working with students in the classroom.

Due to space restrictions, we will limit the discussion on the above questions to a very brief description of some of the main influential trends that we have observed: the combined political, social, organizational and ideological pressures that directly or indirectly compel teaching work to embrace various types of collective work. In the next section, we attempt to show that this sharing is nevertheless ambiguous, as it creates as much work division as collaboration.

\subsection{The Evolution of School Staff}

The first trend is linked to the emergence of the growth, in some countries considerable, of non-teaching school staff. On this issue, we refer the reader to studies conducted by our team (Levasseur \& Tardif, 2005a, b, 2004a, b; Tardif \& Levasseur, 2004, Tardif \& Levasseur, 2010). In the United States, one educational worker out of two is not a teacher. We find a similar trend throughout all developed countries, albeit less striking in Europe. These school staff (some are special educators; others are professionals, technicians or support staff), have gradually, over the last thirty years, taken on a variety of tasks and territories that were traditionally reserved for teachers: guidance, support, counselling, orientation, monitoring, conflict resolution, and managing various types of difficulties, problems, student subgroups, and so forth. Moreover, they frequently occupy new or recently established school work territories: immigrant welcoming programs, early childhood education, learning disorders, and so on. Their presence and above all their growing importance within schools and education systems have driven the introduction of new cooperative and sharing practices with teachers, but also territorial protection and status negotiation strategies. More significantly, these education workers are liable to gradually erode the educational monopoly that teachers have had with their students. The consequence would be a new sharing of school work in response to this issue. We will take this up in the second part.

\subsection{Transformation of School Missions and Knowledge}

A second trend stems from the increasingly complex mandates for instruction, education and qualifications that are affecting both schools and teachers. Schools are currently facing challenges that no human society has even imagined: they must accommodate all children at ever younger ages, retain them as long as possible, and get them to learn knowledge that is increasingly diversified, ample, innovative and recent, while providing not only equality of opportunity at entry, but also equality of treatment along the way, and at the same time attempting to produce the greatest possible number of graduates at the end of the process, graduates who are qualified to work in a widely diversified and volatile labour market. Faced with this critical trend, school reforms in most countries since the 1980s have adopted very similar strategies.

They emphasize transversal approaches and competences to deal with the complexity, diversity and growing importance (in amount and duration) of school learning. In addition, they generally promote a "constructivist" and reflective vision, as opposed to transmissive teaching. Thus, they seek to avoid or refashion the "egg-carton" approach to curriculum organization by creating new and dynamic teaching and learning units that overlap or extend the traditional boundaries of teaching work (e.g., the lesson, the classroom, the grade, the program), and that require teachers to collaborate, work in teams, and share student teaching, monitoring and assessment.

Along with the traditional instructional mandate, they hold teachers and schools responsible for socializing and 
educating students: the curriculum is therefore expanded, at least at the margins, to include areas that are traditionally non-academic, such as values, citizenship, civicmindedness, sexuality, sports, health, and more. In the same way, a set of "extra-curricular" activities has been added, to which teachers and other school staff must devote more and more time. For certain student populations, these "marginal" activities are what keep them in school.

Concerning the curriculum, many countries have brought in reforms that stress collaboration among teachers and within schools. In the United States, teachers are required to employ collaborative practices in "learning communities" aimed to promote more effective teaching and achieve staff development goals (National Board for Professional Teaching Standards - NBPTS, 2001, 2002, National Staff Development Council - NSDC, 2001). In Australia, the Standards of Professional Practice for Accomplished Teaching in Australian Classrooms (2000) encourage teachers to work together in professional and learning communities. Similarly, the General Teaching Council for England (2002) in Great Britain advocates active professional learning as well as openness and questioning in a collaborative learning strategy as part of its school reform. Like Great Britain, other European countries advocate collaborative teaching under their education reforms, including French-speaking Belgium (Frenait \& Maroy, 2004, Dupriez, 2005), France (Barrère, 2001, Lang, 2005) and Switzerland (Périsset-Bagnoud, 2005).

The combined effects of all these changes appear to have carved out a new image of school knowledge: no longer an "egg-carton" curriculum that can be confined and arranged in discrete units (e.g., subjects, disciplines, fields, objectives and divisions) and assigned to individual teachers, it is instead a procedural, dynamic, transversal generic knowledge (defined in terms of the underlying culture, a common culture made up of learning, competences and constructions rather than predetermined content), which requires teachers to adopt new ways of collaborating and sharing.

\subsection{A multiplicity of Professional Roles}

In recent decades, teachers have also faced increasingly heterogeneous student groups and populations, and in some schools, regions and neighbourhoods, these students are much more difficult to handle. This major change means that the image of the "master instructor" is disintegrating and merging with other professional roles that teachers must play in one way or another: social worker, psychologist, educator, parental substitute, police officer, counsellor, and more. Thus, traditional teaching work is split into many parts: to be able to teach, teachers must perform more and different types of work, and must therefore divide their efforts and themselves, which is not so easy for all teachers to do. This causes stress and resistance, especially in secondary schools. To this change are added the new requirements for teachers to participate in school life and school management. Here again, teachers must learn to wear new hats: team coordinator, education project coordinator, head teacher for a grade, school board member, innovation head, program head, and the like. Thus teachers must perform like professional chameleons. Although the classroom remains a refuge, they now have to venture out more often, play new professional roles and learn to negotiate with other education staff.

\subsection{Mobilizing Teaching Teams in Schools}

In the last twenty years, many of the school reforms have aimed to reorganize teaching systems along with their regulation and control mechanisms and to reallocate authority among units (e.g., education departments, school commissions, regional authorities and schools). This transformation, although it varies greatly among countries, generally ends up granting the school greater power and autonomy as the system's nerve centre. Thus, the vision of the school as a unit to which rules must be applied and administered has changed to that of a unit that interprets, adapts, negotiates, and even creates rules and culture. In this perspective, teachers are now members of a "school team," and collaboration becomes a cultural norm and a professional obligation. Teachers must rally around school projects, get involved in a variety of collective initiatives, collaborate with their peers, specialists and other educators, both internal and external, and learn how to cooperate with parents. Like many companies, schools must develop an entrepreneurial or project culture, that is, a learning organization based not only on reflective thinking, but also on the strong emotional investment of its members. In short, the school can no longer be reduced to an administrative unit governed by formal rules. Instead, it becomes a creative environment that produces standards that can only work if they are shared. In such environments, school administrations are called upon to "mobilize their teams," to assume pedagogical leadership, to energize the school and renew its image, and even to sell that image in some countries that prefer to develop extensive private school systems. Therefore, beyond sharing tasks and responsibilities, there is an obligation to share a common culture and norms.

These changes, of which we have only touched the surface, characterize a markedly intense phase since the 1980s, in which the job of teaching was redefined and reconstructed. Like a new hand of cards, the work has been distributed anew, in terms of schools, day-to-day tasks, roles and identities, professional culture, peer relations and relations with other school staff. The result is that, through reforms and education policies as well as social and cultural changes impacting the profession, a new teaching professionalism has emerged that is broader and more pluralistic-albeit less defined, and perhaps more demanding — as well as more flexible, fluid and adaptable to the new functions and responsibilities of both the profession and schools. In all cases, this new professionalism tends to remove shared work practices from the margins to which it was formerly confined and 
place it at the centre of new practices of collaboration, consensus-building, teamwork and collective management.

Nevertheless, this emerging professionalism, which has met with much resistance, as it risks fragmenting the teacher's profession and identity, i.e., a "schoolmaster" focused on classroom work, knowledge transmission, or in high school, subject mastery (Dubet, 2002, Lang, 1999). Furthermore, in a number of countries, it appears to have led to a dualism in the teaching profession, notably through the complex issue of differentiated schools and systems in terms of student populations, "good" and "bad" neighbourhoods, elite and disadvantaged populations, and even excluded communities. In both Europe and North America (and doubtless in Latin America), this new professionalism seems to be demanded more of teachers working in difficult school districts, while elite private schools continue to fiercely defend traditional teaching modes, even if they must be conjoined with the logics of learning organizations and school teams.

Finally, this new professionalism is clearly connected with the transformations that have affected the overall social atmosphere in today's workplaces. Many contend that this professionalism directly reflects the social injunctions imposed on workers in the "knowledge community," for instance, educated workers operating in the noosphere (the sphere of human thought), who are producing non-tangible work in such areas as information, symbols, communication and knowledge. These workers must be flexible, successful, many-sided and possessors of a rainbow of competences. They must learn how to work under pressure, reconfigure their identity so they can handle diverse mandates, develop a subjective and reflective attitude to the job, take themselves in hand as a professional development project, learn how to work in unstable organizations, and participate in shifting collaborative networks, partnerships and teams. In this sense, recent changes in the teaching profession greatly resonate with the transformations that have taken place in the workplace and the new images of workers in highly modernized societies.

\section{Team Teaching in School Work Organization}

To recap, the above-mentioned developments imply that shared work is work under pressure, is evidently being institutionalized, but has unclear and shifting limits. How, then, to address it? We propose some research avenues that appear to be useful and that we have used in recent works.

\subsection{Sharing and Division: Let's not be Naive}

First, we believe that the issue of team teaching cannot be grasped without considering the basic notion of the division of work. It is almost impossible to imagine sharing work without some kind of division of the work. Above all, we must not be lulled into swallowing whole the reformist, educational and pedagogical arguments (and sometimes the arguments of certain researchers who promote teacher collaboration) that continue to convey a largely normative and positive vision of team teaching.

We particularly want to keep in mind that sharing work means collaborating and working together, in other words, solidarity. However, and equally important, it also means dividing, separating, distinguishing, setting apart, differentiating and even setting in opposition. The notion of shared work is therefore semantically ambivalent, as it can mean one thing as well as the opposite: doing what must be done together, accomplishing the job collaboratively, or dividing up the work and doing it separately, each one working alone. We feel that this ambivalence is at the heart of the work relationships in contemporary schools.

On this subject, our research shows that the team teaching issue has emerged over time, as a new standard, value and injunction, in an increasingly divided school work organization. This has been a rather long-standing trend. For example, in Quebec, Mellouki (1994, 1995) found that the number of school staff categories grew from twenty to about a hundred from 1940 to 1970 . Since the early 1980s, these positions have continued to multiply. In our own studies (Lessard \& Tardif, 1996, 1997, Tardif \& Lessard, 1999, Tardif \& Levasseur, 2010), based on the available data, we found around 150 different job positions for non-teaching staff, and almost 220 positions if we count the teachers. Moreover, in recent years, we have investigated the rise of technicians (Levasseur \& Tardif, 2005a, b, Tardif \& Levasseur, 2004). For example, special education technicians, who make up the largest group, accounted for 138 jobs in $1980,3,238$ in $1993,6,441$ in $2001,8,323$ in 2005 and 10,459 in 2011. In Quebec, all the technicians put together hold $23 \%$ of school jobs, including teachers (CSE, 1998; MEQ PERCOS 2001, 2005). These trends are prevalent throughout North America and in several other societies.

Briefly, in the space of about 15 years, the division of the work handled by non-teaching school staff has multiplied by at least ten times. At the same time, all these workers contribute to a new structuring of the work-organization dynamics in schools. They occupy and transform work areas that were already in place and have even created new areas. They complexify school organization by introducing new structures into teaching systems. They upset the central role previously held by regular teachers. These changes have significant repercussions on teaching work:

a) They considerably aggravate coordination problems between non-teaching staff and teachers, and at the same time lead to more bureaucratic control. Thus, team teaching, because it involves this division of work, generates new coordination and control problems in turn, because what was normally divided must now be shared, including work, time, space, knowledge, competences and identities. Teachers all say the same thing: team teaching, with its division of work, consumes a great deal of time and energy. Furthermore, there is always the risk of "stealing" time 
from teaching the students.

b) Because the division of teaching work is inherently unclear, due to its shifting nature (Durkheim, 1973; Cherkaoui, 1978), it necessitates cumbersome regulatory and control systems: regulations, standards, collective agreements, and so on. As these mechanisms grow more ponderous, teachers tend to develop avoidance strategies; the actual work accomplished becomes disconnected from the rules in force or the tasks prescribed by the administration. This is the well-known bureaucratic vicious cycle described by Crozier (1963) over 30 years ago.

c) This division of school work has also profoundly marked the noble school missions of instruction and education. Although, as we have seen, all the reforms aim to promote better integration and greater consistency in education, we must seriously question whether these reforms, with all their good intentions, can really take root in a work organization that suffers from fragmentation, specialized and delineated work areas, differentiated and partitioned staff competences, and the tensions and disputes that inevitably result. In short, although educating students is supposed to be a concerted effort shared with the nonteaching staff, how can the work be shared when the school is also committed to a division of work policy?

In conclusion, we advocate a team teaching approach that reduces the division of work, with its resultant tensions and contradictions that impact all the individuals who are simultaneously engaged in sharing and dividing their tasks, knowledge and work areas.

\subsection{Examining the Actual Organization of Work in Schools}

Irrespective of the setting, whether school or factory, collaboration between workers always comes with costs and benefits, gains and losses, risks and opportunities. Here again, shared work cannot overlook these realities, the tensions between these two poles. In order to understand them, we believe we must examine not only what can be done together, but also what cannot be done together for various reasons. For this reason, we have recently investigated (Borges, 2006; Borges \& Lessard, 2005, 2007) the barriers and constraints to team teaching in high school teachers in the province of Quebec, Canada. We wanted to understand, beyond the very strong reformist insistence on team teaching, the more or less objective reasons for the resistance to sharing.

a) Workplace conditions

The most restricting aspects appear to be conditions that discourage collaborative work, namely lack of time, excessive workload and too large groups and classes of students per teacher. These unfavourable conditions stem from the secondary school's structure and functioning, which have always posed barriers to greater collaboration among teachers: overpacked schedules, ever-increasing workloads-particularly after the implementation of reforms, and the number of groups and students assigned to teachers are just some of the obstacles to shared work, of whatever type.

The lack of time is not just an abstraction; it is associated with a workload filled with a seemingly endless list of tasks to be accomplished and numbers of students and groups to handle in the classroom. Working in collaboration can seem like an insurmountable task as teachers feel exhausted by all the work to be done, as this secondary teacher attests:

[...] My regular work week is 35 hours, but all this takes another 20 hours [...] so that makes a 55-hour week. That means I'm exhausted, and that's a shame, because my students have the right to have a teacher who's awake [..., and who isn't always pressed for time, and sometimes I get the feeling that I'm being shoved around, even though I really want to do a good job, and so do my colleagues.

b) Departmental organization

The departmental culture, for its part, weighs heavily on the teaching culture. Particularly in North America, studies on the departmental life of secondary schools suggest that while teaching is shaped by the content being taught, it is even more influenced by the departmental culture or subculture (Siskin, 1991, Stodolsky \& Grossman, 1995). Culture affects the organization, task allocation, the distribution of power in curricular decisions, climate, environment, recruitment, teacher training, career development and the types of collaborations that teachers set up.

The division into disciplinary departments helps disconnect teachers from each other: "How can we get transversality when we don't even know the teacher in the next classroom?" wonders a teacher of physical and health education. Notwithstanding the reforms, departmentalization is still far from extinguished, and it often generates communication problems between teachers.

c) Disciplinary culture

While departmentalization promotes isolation and lack of communication among teachers, these aspects are even more aggravated by disciplinary culture divisions in secondary schools. All teachers are required to "cover the subject" with their students. As one mathematics teacher complains, "We've got to cover the program! And that's not easy to do. How are we going to collaborate on interdisciplinary projects? I don't have that luxury [...] at the end of the year my students have to have all the concepts."

This is in line with the findings of Siskin (1991), Stodolski and Grossman (1991) and Grossman and Stoldoski (1995) on the concerns of some teachers who feel compelled to cover the complete program, especially in mathematics, a critical subject for admission to higher levels. They appear to feel caught between team teaching with colleagues who teach other subjects and the need to deliver the content to their students so they can pass their exams.

All this generates a feeling of instability in teachers, because even when collaboration takes place, work sharing practices are not necessarily relevant to their own concerns. In addition, teachers usually forge only tenuous links with 
each other, they feel more threatened by shared activities, fearing that their weaknesses will be outed and their reputations tarnished. This is aptly described by Barrère (2002) in his study on collaborative teaching practices in lycées and colleges, where the fear of losing one's reputation, or "losing face" (Rosenholtz, 1999) impels teachers to avoid shared activities.

d) Contradictions between the curriculum and the realities of the job

Under recent curriculum reforms, teachers are required to collaborate to achieve very weighty and ambitious goals, such as developing transversal competences and disciplinary competences, fostering metacognition, promoting the social and personal development of students and integrating at-risk students. At the same time, traditional assessment systems are still in place, whereas education management and funding reflect lower investments in education. Moreover, teachers are required to invest themselves in their work as never before, using work tools and under conditions that sometimes fall short of reformist expectations. In short, in many education systems today, in Quebec as well as many countries (e.g., the United States and Great Britain), the injunction to team teach is combined with a burgeoning teaching workload: more must be done, but with less.

\section{Conclusion: Shared Work and Divided Work}

As we have attempted to show in this brief paper, shared work, which was formerly relegated to the margins, has overflowed the edges of the egg-carton organization and spread out under the simultaneous pressures of the reforms, changes in schools and student populations, the advent of new education professionals and transformations to the teaching profession.

However, although the reconstruction phase of teaching work and the institutionalization of team teaching are well underway, there is still a long way to go, and the main directions remain unclear. Despite considerable efforts to stamp out the classroom cell and the egg-carton organization, they remain core organization modes in teaching work. In this perspective, shared work among teachers, or team teaching, must be viewed as a socioprofessional space that is in the process of being defined and constructed, a shifting space in which pressures, requirements, injunctions, as well as tensions, problems, resistances, rejections and avoidance strategies join their effects, cancel each other out, and turn shared teaching work into a major issue in the current teaching profession.

We believe that the study of team teaching as a new research area should aim to account for these diverse tensions and identify the types and practices of work sharing within the many divisions that characterize teaching in today's schools.

\section{References}

[1] Barrère, A. (2001) Les enseignants au travail. Paris: Harmattan.

[2] Barrère, A. (2002) Pourquoi les enseignants ne travaillent-ils pas en équipe? Sociologie du travail, Elsevier, n. 44, p. 481497.

[3] Borges, C. (2006). Colaboração docente e reforma dos programas escolares no QuebecEducação em Revista, Université fédérale de Minas Gerais, Brésil. No. 44, Décembre p. 229-256.

[4] Borges, C. and Lessard, C. (2005). Enseigner autrement à l'école secondaire? L'annuaire du Quebec 2005. Éditions FIDES, p.329-334

[5] Borges, C. and Lessard, C. (2007). Qu'arrive-t-il quand la collaboration enseignante devient une norme? In.: Marcel, JF., Dupriez, V., Périsset, D. (éd.) In.: Coordoner, collaborer, coopérer, des nouvelles pratiques enseignantes. France/Belgique: DeBoeck.

[6] Dubet, F. (2002) Le déclin de l'institution, Paris : Seuil, coll. L'épreuve des faits.

[7] Durkheim, É. (1973). De la division du travail social, Paris, Presses universitaires de France, 1e édition, 1930.

[8] Cherkaoui, M. (1978). "Système social et savoir scolaire :les enjeux politiques de la distribution des connaissances selon Durkheim", Revue française de science politique, no 2, Paris, 1978, p. 313-349.

[9] Grossman, P.L. and Stodolsky, S.S. (1995) Content as Context: The Role of Subjects Secondary School Teaching. Education Researcher, Washington, DC: AERA, v. 24, n. 8, p. 5-23, Nov.

[10] Lang V. (1999). La professionnalisation des enseignants. Sens et enjeux d'une politique institutionnelle, Paris : PUF, Éducation et Formation.

[11] Lessard, C. (dir.) Nouvelles régulations et professions de l'éducation. Éducation et Sociétés, n $6,2000 / 2$.

[12] Levasseur, L. and Tardif, M. (2005). «Les rapports professionnels entre les techniciens et les enseignants dans la division du travail au Quebec », Éducation et société. Revue internationale de sociologie de l'éducation, Paris, Institut national de la recherche pédagogique, De Boeck, numéro 15,1 , pp. 169-188.

[13] Levasseur, L. and Tardif, M. (2005). «L'essor du travail technique en milieu scolaire et son incidence sur l'organisation du travail » in Recherches sociographiques, Université Laval, XLVI, 1, pp.97-118.

[14] Levasseur, L. and Tardif, M. (2004). «Transformation de l'enseignement à la lumière de l'essor du travail des techniciens scolaires», Numéro thématique sur les Transformations de l'acte d'enseigner: segmentation et délégation. Revue Les sciences de l'éducation? pour l'ère nouvelle, Caen, France, volume 37, no 1, pp. 29-45.

[15] Lortie, D. (1975). School-Teacher: a sociological study. Chicago III : Chicago Press.

[16] Maroy, C. (2006). Ecole, régulation, marché. Paris: PUF. 
[17] Ministère de l'Éducation (2005, 2010). Base de données PERCO. Québec : Gouvernement du Québec.

[18] National board for professional teaching standards (NBPTS). (2001). Five core propositions. http://www.nbpts.org/the_standards/the_five_core_propositi o.

[19] NBPTS. (2002). What teachers should know and be able to do. National Office. Arlington, Va/Southfield, MI, USA. www.nbpts.org. 22p.

[20] National Staff Development Council (NSDC). Resolutions. http://www.nsdc.org/connect/about/resolutions.cfm National Staff Development Council. Standards for Staff Development, $\quad$ revised 2001. http://www.nsdc.org/standards/index.cfm.

[21] Ontario College teachers. Standards of practice for the Teaching profession. Government of Ontario, Canada, 1999.

[22] Siskin, L.S. (1991). Departments as Different Worlds: Subject Subcultures in Secondary Schools. Educational Administration Quarterly, Salt Lake City: University of Utah, v. 27, n. 2, p. 134-160, May.
[23] Standards of Professional Practice for Accomplished Teaching in Australian Classrooms. National Discussion (2000). Paper on Professional Teaching Standards. Publish by: Australian College for education (ACE), Australian Curriculum Studies Association (ACSA) et Australian Association for Research in education (AARE).

[24] Stodolsky, S. S. (1993). A framework for subject matter comparisons in high school. Teaching and Teacher Education, n. 9, p. 333-346.

[25] Stodolsky S. S. and Grossman, P. L.. (1995). The Impact of Subject Matter on Curricular Activity: An Analyses of five Academic Subjects. American Educational Research Journal, Washington, DC: AERA, v. 32, n. 2, p. 227-250.

[26] Tardif, M. and Lessard, C. (2004). La profession d'enseignant aujourd'hui. Évolutions, perspectives et enjeux internationaux. Quebec/Belgique: Presses de l'Université Laval/de Boeck, 313 p.

[27] Tardif, M. and Levasseur, L. (2003). Formes et enjeux de la division du travail dans l'école nord-américaine. Revue Politiques d'éducation et de formation. Analyses et comparaisons internationales, Louvain, De Boeck Éditeur, 2002, pp. 95-109. 